\title{
Performance of grid-connected solar photovoltaic power plants in the Middle East and North Africa
}

\author{
Jalal Assadeg', Kamaruzzaman Sopian², Ahmad Fudholi ${ }^{3}$ \\ ${ }^{1,2,3}$ Solar Energy Research Institute, Universiti Kebangsaan Malaysia, Malaysia \\ ${ }^{1}$ Renewable Energy Eng. Dept-Collage of Energy and Mining Engineering, Libya
}

\section{Article Info \\ Article history: \\ Keywords: \\ Grid-connected \\ Photovoltaic \\ Power plant \\ Solar fraction \\ Utilizability}

Received Feb 5, 2019

Revised Apr 8, 2019

Accepted Apr 9, 2019

\section{Corresponding Author:}

Kamaruzzaman Sopian,

Solar Energy Research Institute, Universiti Kebangsaan Malaysia, 43600 Bangi Selangor, Malaysia. Email: k.sopian@ukm.edu.my

\begin{abstract}
A conceptual design study of a grid connected solar electric power system using PV array for a 5.3MW as nominal power required is presented. A Bird model has been used to estimate hourly, daily, monthly and yearly solar radiation amounts. $\phi$-f-chart is a design method was chosen to simulate the fraction of the solar energy required for the load given the PV array areas and climatic conditions. Four cities in the Middle East and North Africa representing different locations at southern mediterranean region are selected Tripoli, Alexandria, Tunisia and Gaza city. Tripoli City has the best performance for $73 \%$ of nominal Power followed by Alexandria about $66 \%$ and then Gaza around 63\%, Tunisia City has lowest solar fraction about 59\% according to the Monthly and annual solar fraction Data.
\end{abstract}

Copyright () 2019 Institute of Advanced Engineering and Science. All rights reserved.

\section{INTRODUCTION}

Photovoltaic systems are the most promising renewable energy source in north Africa and MiddleEast due to its abundant solar irradiation [1-3]. PV systems classified in three main types; stand-alone, hybrid and grid connected PV system as shown in Figure 1. Stand-alone pv systems required battery energy storage for DC mode or with inverter for AC mode but others without battery bank and linked directly to a load $[4,5]$. hybrid PV system is composed of PV solar panels with other source of energy like wind farm, fuel cell or water turbines[4, 6-8]. Grid connected pv system is the best option that using PV panels directly with grid to supply any reduction in electrical energy from solar panel array with or without battery storage $[4,9,10]$.

In grid- connected application, also called On-grid application such as a system the Photovoltaic array feed electrical energy directly into electrical grid (included central -grid and isolated grids) [11-13]. Batteries are not necessary when the system is grid-connected or on-grid. The selected application is installation of PV generators (PV array) by utilities at Power substation after that to central grid. This application can be on the threshold of cost competitiveness for PV depending in location. The benefits of grid can be on the threshold of cost competitiveness for PV depending in location. Also grid-connected PV power generation is generally evaluated based on its potential to reduce costs for energy production and generators (PV) are located at or near the site of electrical consumption. In addition, the utility can avoid or delay upgrades to transmission and distribution network where the average daily output of the PV system corresponds with the utility's peak demand period [14]. 




Figure 1. Classification of photovoltaic system

\section{CONCEPTUAL DESIGN}

The proposed power plant as shown in Figure 2 is composed of solar PV array and electrical inverters which are conncted to conventional fossil fuel power plant (CFPP), electrical substation (ESS) and electrical pwer grid (EPG). Solar PV array is consisted of number of solar panls conncted in parallel and series. The selected solar panel in this study has maximum efficiency about $19 \%$, and its area is $1.580 \times 0.812$ $\mathrm{m}^{2}$ with maximum power equal to $245 \mathrm{Watt}$ where is available online in international Markets around $100 \$$. The system has multidimensional areas in different four options according to number of the used solar panel. Overall area of PV array equal to $80 \times 10^{3} \mathrm{~m}^{2}$ for 62500 solar panels, $60 \times 10^{3} \mathrm{~m}^{2}$ of 46875 solar panels, $40 \times 10^{3} \mathrm{~m}^{2}$ of 31250 solar panels and $20 \times 10^{3} \mathrm{~m}^{2}$ for 15625 solar panels.

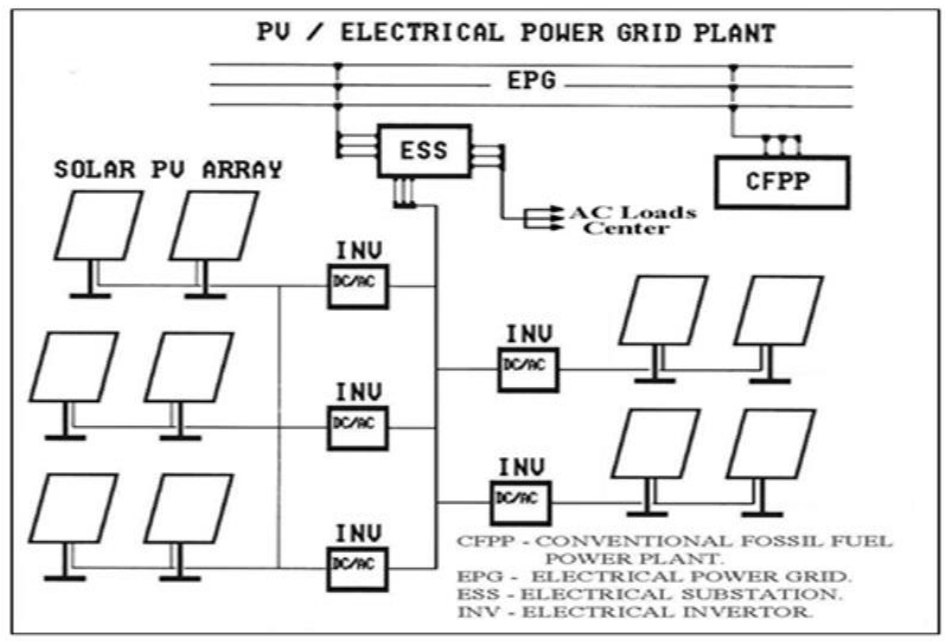

Figure 2. Schematic of propsed solar electrical power plant

\section{MATHMATICAL MODEL}

The Bird Clear Sky Model, authored by Richard Bird, is a broadband algorithm which produces estimates of clear sky direct beam, hemispherical diffuse, and total hemispherical solar radiation on a horizontal surface the equations composed of simple algebraic expressions with 10 user provided inputs. Model results should be expected to agree within $\pm 10 \%$ with rigorous irradiative transfer codes. The model computes hourly average solar radiation for every hour of the year, based on the 10 user input parameters; however variable atmospheric parameters such as Aerosol Optical Depth, Ozone, Water vapor are fixed for the entire year. 
The total amount of ozone $I_{0}$ in the atmosphere as a vertical column is given in units of atmosphere given by [15]:

$$
\begin{aligned}
I o= & J_{1}+[Y a+C \sin (D(n+F))]+G \sin [Z(\alpha+I)] \times \\
& \times\left[\sin ^{2}(Y b * \Phi)\right]
\end{aligned}
$$

For a homogeneous atmosphere was calculated by Kasten which provides an accuracy of $99.6 \%$ for zenith angles up to $89^{\circ}[16]$ :

$$
m=\left[\sin \gamma_{s}+0.50572 \times\left(\gamma_{s}+6.079\right)^{-1.6364}\right]^{-1}
$$

A modified relationship for air mass has also been suggested by [17]:

$$
m=\left[\sin \gamma_{s}+0.00176759 \times\left(\gamma_{s} \times\left(94.37515-\gamma_{s}\right)\right)^{-1.21563}\right]^{-1}
$$

The above equations are applicable to a standard pressure P0 of $1013.25 \mathrm{mbar}$ at sea level, for other pressures the air mass may be corrected as $[18,19]$ :

$$
m^{\prime}=m \times\left[\frac{P}{1013.25}\right]
$$

where $\mathrm{P}$ is atmospheric pressure (in bar) at height $\mathrm{H}$ (metres above sea level). If $\mathrm{P}$ is not known an approximate formula due to may be used [20]:

$$
\frac{P}{P_{o}}=\operatorname{Exp}(-0.0001184 \times h)
$$

According to Beer's law, the attenuation of light through a medium is proportional to the distance traversed in the medium and the local flux of radiation $[18,19]$ :

$$
I_{b}=I_{s o} \times \operatorname{Exp}(-k m)
$$

$\mathrm{I}_{\text {so }}$ is computed by [19]:

$$
I_{s o}=1367 \times[1+0.033 \cos (0.0172024 n)] \times \sin \gamma_{s}
$$

Defining the transmission coefficient previous equation written as:

$$
I_{b}=I_{s o} \times \tau
$$

Ozone and water vapor transmittances are considered:

$$
I_{b}=I_{s o} \times \tau_{r} \times \tau_{g} \times \tau_{\alpha} \times \tau_{0} \times \tau_{w}
$$

The transmittance coefficient due to aerosol scattering written as [16]:

$$
\tau_{\alpha}=\int_{\lambda=0.3 \mu m}^{3 \mu m} \tau_{\alpha \lambda} d \lambda=\int_{\lambda=0.3 \mu m}^{3 \mu m} \exp \left(-\beta \lambda^{-\alpha} m_{\alpha}\right) d \lambda
$$

An alternate way of estimating $\tau_{\alpha}$ is the relationship is given by:

$$
\begin{aligned}
& k_{\alpha}=0.2758 k_{\alpha \tau=0.5 \mu m}+0.35 k_{\alpha \tau=0.5 \mu m} \\
& \tau_{\alpha}=\exp \left[-k_{\alpha}^{C O F(1)}\left(1+k_{\alpha}-k_{\alpha}^{C O F(2)}\right) m^{\prime C O F(3)}\right.
\end{aligned}
$$


Also according to Lacis and Hansen can calculated $\tau_{\mathrm{o}}$ and $\mathrm{x}_{\mathrm{o}}$ :

$$
\begin{aligned}
\tau_{0}= & 1-\left[0.1611 \mathrm{x}_{\mathrm{o}}\left(1+139.48 \mathrm{x}_{0}\right)^{-0.3035}-\right. \\
& \left.-0.002715 \mathrm{x}_{0}\left(1+0.044 \mathrm{x}_{0}+0.0003 \mathrm{x}_{0}^{2}\right)^{-1}\right] \\
x_{0}= & I_{0} \times m
\end{aligned}
$$

For transmittance of water vapour $\tau_{\mathrm{w}}$, transmittance of ozone absorptance $\tau_{\mathrm{o}}$ and total amount of perceptible water $\mathrm{x}_{\mathrm{W}}$ is calculated by relations:

$$
\begin{aligned}
\tau_{w} & =\operatorname{COF}(4)-\operatorname{COF}(5) m^{\prime}+\operatorname{COF}(6) m^{\prime 2}-C O F(6) m^{3}+ \\
& +C O F(6) m^{\prime 4} \\
x_{W} & =I_{W} \times m \\
\tau_{g}= & \exp \left[-\operatorname{COF}(13) m^{\prime C O F(14)}\right]
\end{aligned}
$$

The clear-sky diffuse irradiance model is based on [21, 22]:

$$
I_{d}=I_{s o} \tau_{\alpha \alpha} \tau_{g} \tau_{0} \tau_{w}\left[\frac{0.5\left(1-\tau_{r}\right)}{1-m+m^{1.02}}+\frac{0.84\left(1-\tau_{\alpha s}\right)}{1-m+m^{1.02}}\right]
$$

For calculation of $\tau_{\alpha \alpha}$ and $\tau_{\alpha s}[22,23]$ :

$$
\begin{aligned}
& I_{b}=1-0.1\left(1-\tau_{\alpha}\right)\left(1-m+m^{1.02}\right) \\
& \tau_{\alpha s}=10^{-0.045 m^{\prime} 0.7}
\end{aligned}
$$

The global irradiance on horizontal surface $\mathrm{I}_{\mathrm{G}}$ is given by[20]:

$$
I_{G}=\left(I_{b}+I_{d}\right)\left(\frac{1}{1-r_{s} r_{\alpha}^{\prime}}\right)
$$

$r_{s}$ is the ground albedo ( a standard value of 0.2 is often quoted), $r_{\alpha}^{\prime}$ is the albedo of the cloudless sky.

\subsection{Monthly solar radiation}

$R$ is the monthly ratio of radiation on a tilted surface to radiation on a horizontal surface. It is known as the monthly mean total radiation tilted factor and is given by[19]:

$$
\begin{aligned}
& \overline{\mathrm{Hb}}=\int_{\mathrm{Hst}}^{\mathrm{Hft}} \mathrm{Ib} * \mathrm{~d} \tau \\
& \overline{\mathrm{Hd}}=\int_{\mathrm{Hst}}^{\mathrm{Hft}} \mathrm{Id} * \mathrm{~d} \tau \\
& \bar{H}_{G}=\overline{H_{b}}+\overline{H_{d}}
\end{aligned}
$$

For calculate monthly average beam radiation tilt factor and given by[19]:

$$
\bar{R}_{b}=\frac{\cos (\Phi-\mathrm{B}) \cos \delta \sin \omega_{s}^{\prime}+\left(\frac{\pi}{180}\right) \omega_{s}^{\prime} \sin (\Phi-\mathrm{B}) \sin \delta}{\cos \Phi \cos \delta \sin \omega_{s}^{\prime}+\left(\frac{\pi}{180}\right) \omega_{s}^{\prime} \sin \Phi \sin \delta}
$$


For calculate HT by using [20]:

$$
\begin{aligned}
\bar{H}_{T}= & \bar{H}\left(1-\frac{\bar{H}_{d}}{\overline{H G}}\right) \bar{R}_{b}+\bar{H}_{d}\left(\frac{1+\cos \beta}{2}\right)+ \\
& +\bar{H} \rho g\left(\frac{1-\cos \beta}{2}\right)
\end{aligned}
$$

\subsection{Modeling of the electrical power plant}

The array is characterized by its overall average efficiency, $\eta_{p}$ which is a function of average module and cell tempretuter $\mathrm{T}_{\mathrm{c}}[24]$ :

$$
\eta_{p}=\eta_{r}\left[1-\beta_{p}(T c-T r)\right\rfloor
$$

where $\eta_{r}$ is the PV model efficiency at reference temperature $\mathrm{T}_{\mathrm{r}}\left(=25^{\circ} \mathrm{C}\right)$, and $\beta_{P}$ is the temperature coefficient of module efficiency. $\mathrm{T}_{\mathrm{c}}$ is related to the mean monthly ambient temperature $\mathrm{T}_{\mathrm{a}}$ through Evans' formula [20]:

$$
T_{c}-T_{a}=\left(219+832 \overline{K_{t}}\right) \times \frac{T_{n}-20}{800}
$$

whereas $\mathrm{T}_{\mathrm{n}}$ is the nominal operating cell temperature and $\overline{K_{t}}$ the monthly clearance index, $\mathrm{T}_{\mathrm{n}}$ and $\beta_{p}$ depend on the type of PV module.

$$
C f=1-0.0000117 \times(\Phi-\delta-\beta)^{2}
$$

whereas correction factor for the tilted angle of the solar panel array is the monthly energy delivered by the solar panel is $\overline{E_{p}}$ :

$$
\overline{E_{p}}=\eta_{p} \times \overline{H_{T}} \times A_{p}
$$

Overall area $A_{\text {system }}$ of solar electric power system:

$$
A_{s y s t e m}=A_{p} \times N_{p}
$$

The monthly average daily electrical energy of solar electric power system is then given by [19, 25]:

$$
\bar{Q}=\frac{\bar{E}_{p}}{A_{p}} \times \eta_{\text {inv }} \times A_{s y s t e m} \times(1-\lambda p)(1-\lambda a)
$$

The monthly and annual solar fraction $S F$ is defined as electrical energy of solar electric power system divide by nominal power required to the load:

$$
S F=\frac{\bar{Q}}{5.3 M W}
$$

\section{RESULTS AND OBSERVATIONS}

Figure 3 to Figure 5 illustrate the climatological data for the selected cities in Middle East and north Africa which are located on Mediterranean basin. Figure 3 shows the monthly average daily insolation on a horizontal surface, $\overline{\mathrm{H}}$; Figure 4 indicates the average daytime ambient temperature Ta; and Figure 5 represents the monthly clearness index, Kt. Selected PV panel has maximum efficienc about $19 \%$, and its area is $1.580 \times 0.812 \mathrm{~m} 2$, maximum power of solar panel $245 \mathrm{~W}, \mathrm{Tc}=45 \mathrm{oC}$, electrical inverter has efficiency about $99 \%$ and slope equal to latitude plus 5 degrees. The latitude \& longitude of the cities are

Performance of grid-connected solar photovoltaic power plants in the Middle East and .... (Jalal Assadeg) 
$32^{\circ} 52^{\prime} \mathrm{N} \& 13^{\circ} 11^{\prime} \mathrm{E}, 31^{\circ} 20^{\prime} \mathrm{N} \& 2^{\circ} 91^{\prime}, 33^{\circ} 88^{\prime} \mathrm{N} \& 9^{\circ} 53^{\prime} \mathrm{E}$ and $31^{\circ} 50^{\prime} \mathrm{N} \& 34^{\circ} 46^{\prime} \mathrm{E}$ for Tripoli, Alexandria, Tunisia and Gaza respectively. The solar arrays area Asystem equal to $80 \times 103 \mathrm{~m}^{2}$ for 62500 solar panels, $60 \times 103 \mathrm{~m}^{2}$ of 46875 solar panels, $40 \times 103 \mathrm{~m}^{2}$ for 31250 solar panels and $20 \times 103 \mathrm{~m}^{2}$ for 15625 solar panels. The temperature coefficient of module is $0.00431 / \mathrm{oC}$. The nominal electrical power of system $5.3 \mathrm{MW}$ in daytime to Grid, using equations (1) through (33), the monthly and annual fraction of solar energy delivered by solar array to load has been calculated. For calculate Ib and Id by Bird model from equation (1) through (21) the Iteration is to be continued from sunrise until sunset hours of a day.

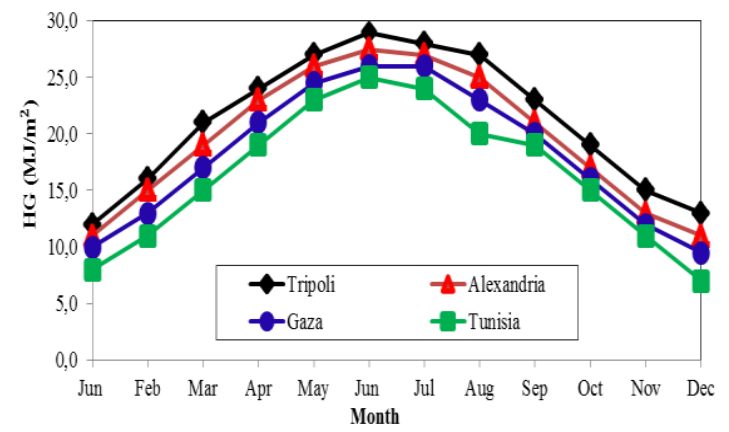

Figure 3. Monthly average daily insolation on a horizontal

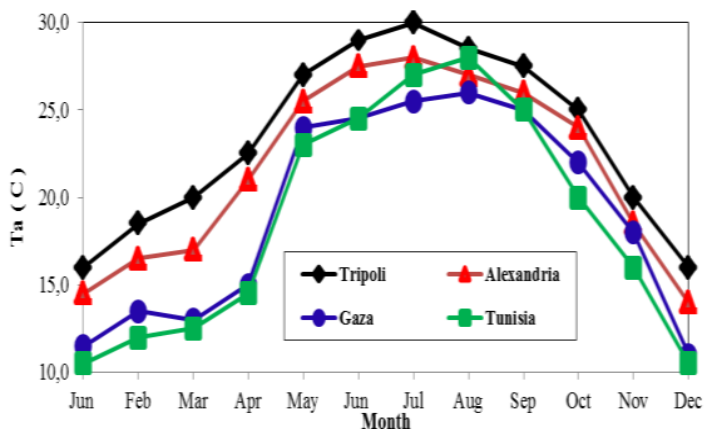

Figure 4. Monthly average daily ambient temperature

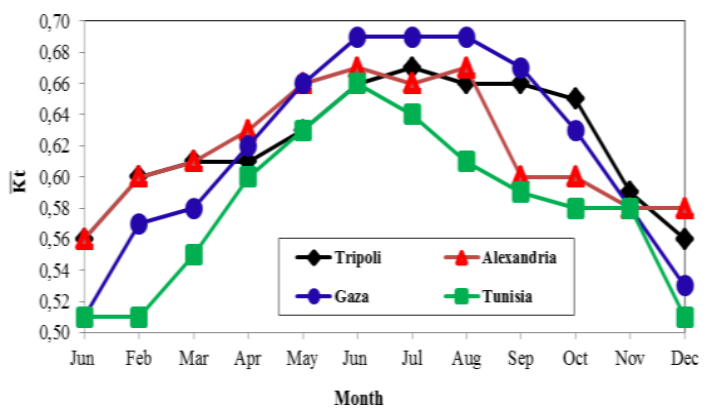

Figure 5. Monthly clear sky index $\overline{\mathrm{Kt}}$

\subsection{Monthly solar fraction}

Figures 6 through 9 represent the monthly fraction of the solar energy delivered by solar PV array each month for each city. The highest monthly solar fraction was obtained at Tripoli as shown in Figure 6. More than $79 \%$ of the energy is provided by the solar energy for the month of March and April with a system area $\left(A_{\text {system }}=80 \times 10^{3} \mathrm{~m}^{2}\right)$ for 62500 solar panels and minimum solar fraction with the same area in June about $69 \%$. Alexandria City obtained its highest monthly solar fraction in January about $73 \%$, on the other words the solar frication is always above $60 \%$ throughout the year as shown in Figure 7.

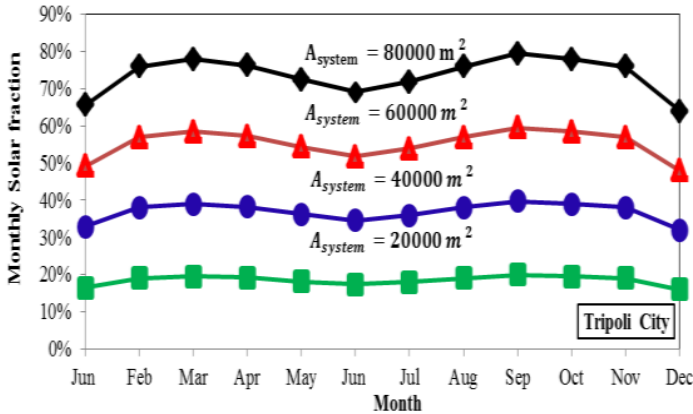

Figure 6. Monthly solar fraction for Tripoli with nominal power plant 5.3MW

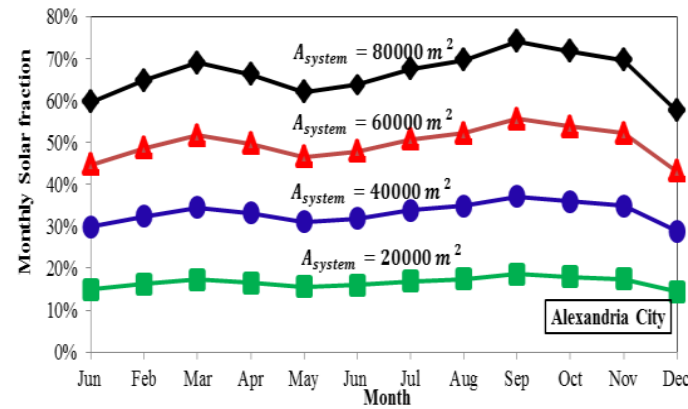

Figure 7. Monthly solar fraction for Alexandria with nominal power plant 5.3MW 


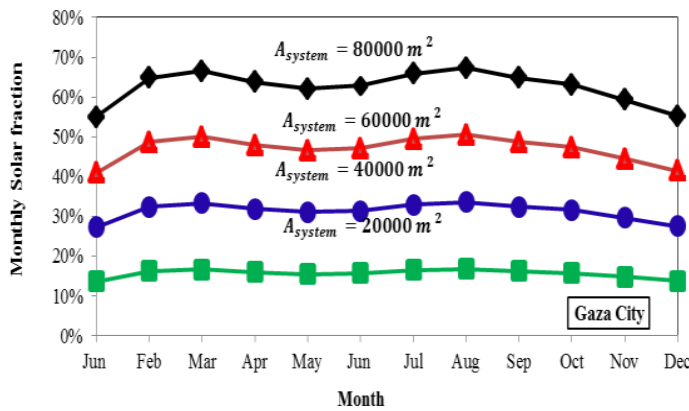

Figure 8. Monthly solar fraction for Gaza with nominal power plant 5.3MW



Figure 9. Monthly solar fraction for Tunisia with nominal power plant 5.3MW

Gaza City obtained its highest monthly solar fraction in March and September. In addition, during summer season, a drastic drop in solar fraction is obvious in June because affected by slope angle of PV array is fixed; in other word, incidence angle is large in June and May as well. The solar fraction reaches above $67 \%$ for september and october. The solar fraction in Tunisia City has a monthly solar fraction ranging between $51 \%$ to $62 \%$. The Highest solar fraction obtained in March and September for PV array area equal to $80 \times 10^{3} \mathrm{~m}^{2}$.

\subsection{Yearly solar fraction}

Annual solar fraction of solar energy delivered by PV array or system as a function of system area (overall area of PV array) is shown in Figure 10. The annual solar fraction increases with the system area $\left(A_{\text {system }}\right)$ that means the larger system area, will give higher energy delivered. Moreover, increases ambient temperature lead to decrease the efficiency and produced energy the factor mentioned-above effected directly on the efficiency and the energy, Tripoli has highest annually solar fraction whereas the maximum its solar fraction about $75 \%$ with larger area of the system followed by Alexandria City and then Gaza City. Tunisia City has the lowest yearly solar fraction. whereas the maximum its solar fraction about $60 \%$. Alexandria City and then Gaza City have solar fraction less than $75 \%$ and more than $60 \%$.

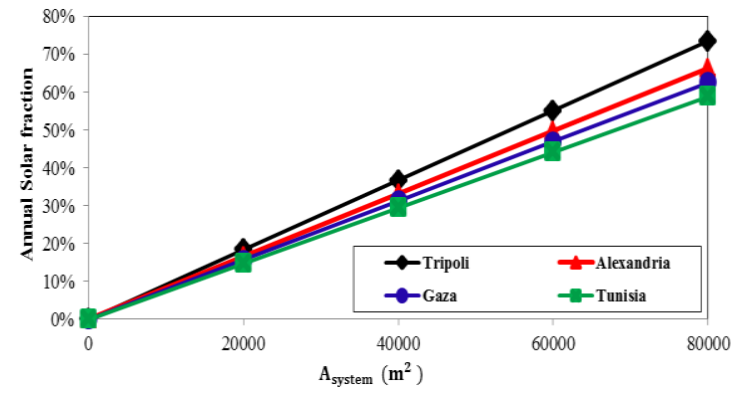

Figure 10. Annual solar fraction of power plant for selected cities

\section{CONCLUSION}

The theoretical study and evaluation of grid connected with solar electric system using PV arrays was presented. Four cities in Middle East and north Africa are selected namely; Tripoli, Alexandria, Gaza and Tunisia were representing different locations within southern Mediterranean basin. The Bird model was used to estimate solar radiation components. Tripoli City has the best performance on both monthly and yearly solar fraction, followed by Alexandria City and then Gaza City. Tunisia City has the lowest yearly solar fraction. An economic analysis must be carried out to determine the economic feasibility of such system in southern Mediterranean region.

\section{ACKNOWLEDGEMENTS}

The authors would like to thank the staff of Solar Energy Research Institute (SERI) for their unlimited support and Universiti Kebangsaan Malaysia (UKM) in general 


\section{Nomenclature}

$\mathrm{P}_{\mathrm{o}} \quad$ Standard atmospheric pressure.

$\beta \quad$ Angstrom's turbidity coefficient.

$\mathrm{k}_{\alpha \lambda} \quad$ Angstrom's turbidity.

$r_{s} \quad$ Ground albedo.

$\mathrm{r}_{\alpha}^{\prime} \quad$ Rayleigh scattering transmittance

$\mathrm{I}_{\mathrm{w}} \quad$ Amount of perceptible water

$\mathrm{I}_{\mathrm{o}} \quad$ Amount of Ozone

$\mathrm{x}_{\mathrm{o}} \quad$ Total amount of ozone in a slanted path

$\mathrm{x}_{\mathrm{w}} \quad$ Total amount of perceptible water

$\tau_{\alpha} \quad$ Transmittance of aerosol absorptance $\gamma_{\mathrm{s}} \quad$ Solar altitude angle

$\tau_{\alpha s} \quad$ Transmittance coefficient.

$\tau_{r} \quad$ Transmittance of Rayleigh scattering.

$\tau_{0} \quad$ Transmittance of ozone absorptance.

$\tau_{\mathrm{w}} \quad$ Transmittance of water vapor.

$\tau_{\mathrm{g}} \quad$ Transmittance of uniformly.

$\tau_{\alpha \alpha} \quad$ Transmittance of aerosol absorptance

$m \quad$ Air mass

$\mathrm{m}^{\prime} \quad$ Pressure - corrected of Mass

C, D, Z, I, F, Ya, Yb Constants for water vapor

\section{REFERENCES}

[1] O. S. Bolaji, et al., "Morphology of the equatorial ionization anomaly in Africa and Middle East due to a sudden stratospheric warming event," Journal of Atmospheric and Solar-Terrestrial Physics, vol. 184, pp. 37-56, 2019.

[2] O. Nematollahi, et al., "Energy demands and renewable energy resources in the Middle East," Renewable and Sustainable Energy Reviews, vol. 54, pp. 1172-1181, 2016.

[3] N. S. Chukwujindu, "A comprehensive review of empirical models for estimating global solar radiation in Africa," Renewable and Sustainable Energy Reviews, vol. 78, pp. 955-995, 2017.

[4] S. Goel and R. Sharma, "Performance evaluation of stand alone, grid connected and hybrid renewable energy systems for rural application: A comparative review," Renewable and Sustainable Energy Reviews, vol. 78, pp. 1378-1389, 2017.

[5] I. A. Ibrahim, et al., "Optimal modeling and sizing of a practical standalone PV/battery generation system using numerical algorithm," 2015 IEEE Student Conference on Research and Development (SCOReD), pp. 43-48, 2015.

[6] L. Bartolucci, et al., "Hybrid renewable energy systems for household ancillary services," International Journal of Electrical Power \& Energy Systems, vol. 107, pp. 282-297, 2019.

[7] Z. M. Omara, et al., "Improving the productivity of solar still by using water fan and wind turbine," Solar Energy, vol. 147, pp. 181-188, 2017.

[8] J. A. Razak, et al., "Optimization of PV-wind-hydro-diesel hybrid system by minimizing excess capacity," vol/issue: 25(4), pp. 663-671, 2009.

[9] R. Hasan, et al., "Grid-connected isolated PV microinverters: A review," Renewable and Sustainable Energy Reviews, vol. 67, pp. 1065-1080, 2017.

[10] A. M. Humada, et al., "Modeling and characterization of a grid-connected photovoltaic system under tropical climate conditions," Renewable and Sustainable Energy Reviews, vol. 82, pp. 2094-2105, 2018.

[11] A. Anzalchi and A. Sarwat, "Overview of technical specifications for grid-connected photovoltaic systems," Energy Conversion and Management, vol. 152, pp. 312-327, 2017.

[12] A. H. Ali, et al., "Performance investigation of grid connected photovoltaic system modelling based on MATLAB simulation," International Journal of Electrical and Computer Engineering, vol. 8, pp. 4847-4854, 2018.

[13] S. N. Rao, et al., "Grid connected distributed generation system with high voltage gain cascaded DC-DC converter fed asymmetric multilevel inverter topology," International Journal of Electrical and Computer Engineering, vol. 8, pp. 4047-4059, 2018.

[14] J. Zhao, et al., "A distributed optimal reactive power flow for global transmission and distribution network," International Journal of Electrical Power \& Energy Systems, vol. 104, pp. 524-536, 2019.

[15] T. K. V. Heuklon, "Estimating atmospheric ozone for solar radiation models," Solar Energy, vol/issue: 22(1), pp. 63-68, 1979.

[16] F. Kasten, "The linke turbidity factor based on improved values of the integral Rayleigh optical thickness," Solar Energy, vol/issue: 56(3), pp. 239-244, 1996.

[17] C. Gueymard, "Critical analysis and performance assessment of clear sky solar irradiance models using theoretical and measured data," pp. 121-138, 1993.

[18] M. Alghoul, et al., "Evaluation of Water Vapour Thickness on Solar Radiation Budget," 2009.

[19] J. A. Duffie, "Solar Engineering of Thermal Processes," 4th Edition ed. New York, John Wiley \& Sons, 2013.

[20] Y. El Mghouchi, et al., "New model to estimate and evaluate the solar radiation," pp. 225-234, 2014.

[21] D. Pisimanis, et al., "Estimating direct, diffuse and global solar-radiation on an arbitrarily inclined plane in Greece," pp. 159-172, 1987.

[22] R. E. Bird and R. L. Hulstrom, "A Simplified Clear Sky Model for Direct and Diffuse Insolation on Horizontal Surfaces," 1981.

[23] M. Alghoul, et al., "Impact of Aerosol Optical Depth on Solar Radiation Budget," 2009.

[24] A. Pradhan, et al., "Experimental Analysis of Factors Affecting the Power Output of the PV Module," International Journal of Electrical Power \& Energy Systems, vol/issue: 7(6), pp. 3190, 2017.

[25] S. E. Mankour, et al., "Modeling and Simulation of a Photovoltaic Field for $13 \mathrm{KW,"} \mathrm{International} \mathrm{Journal} \mathrm{of}$ Electrical Power \& Energy Systems, vol/issue: 7(6), 2017. 


\section{BIOGRAPHIES OF AUTHORS}
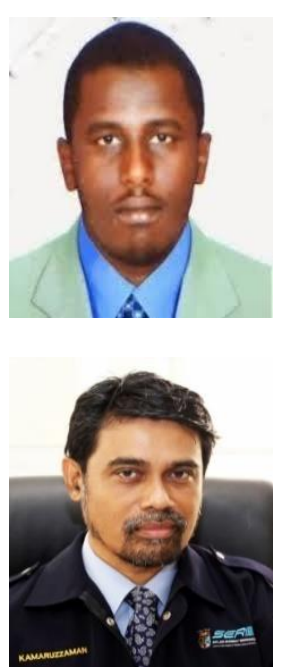

Kamaruzzaman Sopian graduated with the BS Mechanical Engineering from the University of Wisconsin-Madison in 1985, the MS in Energy Resources University of Pittsburgh in 1989 and $\mathrm{PhD}$ in Mechanical Engineering from the Dorgan Solar Laboratory, University of Miami at Coral Gables in 1997. He has been involved in the field of renewable energy for more than 25-years.He has secure research funding from the Malaysian Minstry of Science and Malaysian Ministry of Education and industry for more than USD 6 million. He has conducted renewable enery courses the Asian School of Energy (2007-2014) funded by ISESCO, COMSAT, TIKA and UNESCO.

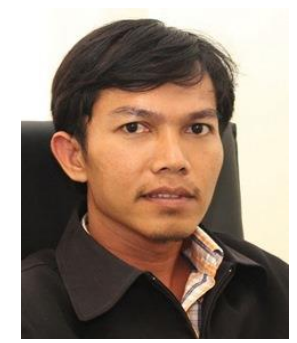

Ahmad Fudholi, Ph.D, M.Sc graduated his Bachelor degree (S.Si) in physics (2002). He was born in 1980 in Pekanbaru, Indonesia. He served as was the Head of the Physics Department at Rab University Pekanbaru, Riau, Indonesia, for four years (2004-2008). A. Fudholi started his master course in Energy Technology (2005-2007) at Universiti Kebangsaan Malaysia (UKM). After obtaining his Master's, he became a research assistant at UKM until. After his Ph.D (2012) in renewable energy, he became postdoctoral in the Solar Energy Research Institute (SERI) UKM until 2013. He joined the SERI as a lecturer in 2014. 